\title{
Mapping Civil Society in the Middle East: The Cases of Egypt, Lebanon, and Turkey
}

\author{
Özlem Altan-Olcay and Ahmet Içduygu
}

\section{Contact information:}

Mailing address:

Koç University

Department of International Relations

Rumelifeneri Yolu, Sariyer

Istanbul 34450

Turkey

\section{Emails:}

ozaltan@ku.edu.tr / oa225@nyu.edu and aicduygu@ku.edu.tr

Tel: Tel: 902123381617 and 1689

Fax: 902123381642

Özlem Altan-Olcay is an assistant professor at the International Relations Department of Koç University.

Ahmet İçduygu is a professor at the International Relations Department of Koç University. 


\section{Mapping Civil Society in the Middle East: The Cases of Egypt, Lebanon, and Turkey}

This paper comparatively assesses the meaning of civil society in Egypt, Lebanon, and Turkey, by utilizing the results of a study conducted among civil society actors. In the recent decades, civil society has become integral to discussions of political liberalization. At the same time, there is a growing rift between international democracy promotion through investment in civil society and the more critical literature on the relationship between the two. This article makes three contributions to these debates by comparing the actual experiences of civil society actors. First, it argues that the boundaries between states and civil societies are indeterminate, making it problematic to expect civil society organizations alone to become catalysts for regime transformation. Second, it shows that expectations of monolithic generation of civic values through civil society organizations do not reflect the actual experience of actors in this realm. Finally, it argues for taking into consideration other social formations and mobilizations as potential contributors to meaningful political and social transformation. 


\section{Mapping Civil Society in the Middle East: \\ The Cases of Egypt, Lebanon, and Turkey}

In the 1990s and 2000s, civil society has become integral to discussions of how to liberalize societies and democratize political regimes. At the same time, there is a growing rift between democracy promotion through investment in civil society and the more critical literature on the relationship between the two. This paper studies the results in Egypt, Lebanon, and Turkey, of a worldwide comparative survey among civil society actors with two goals in mind: to reassess comparatively the meanings and values associated with civil society in these countries and re-evaluate the ways in which experiences of civil society actors themselves speak to scholarly concerns on the topic.

These three countries were the only ones included from the Middle East in a 53country survey carried out by the partners of CIVICUS, the World Alliance for Citizen Participation between 2003 and 2006, which is the first study of its kind to collect reflexive discussions on civil society in this many countries in a comparative perspective. The Civil Society Index (CSI) Study of CIVICUS analyzes perceptions of civil society organizations (CSOs), based on self-evaluations of civil society activists and stakeholders. CSI specifically engages with their self-definitions, dispositions, and concerns, as they map the potential that they envisage for their societies. ${ }^{1}$ The uniqueness of this article stems, firstly, from its comparative nature. It brings together the experience of civil society actors located in distinct regime types. Egypt's authoritarian state, Lebanon's hybrid regime with a past of failed state and Turkey's uneasy location between a hybrid regime and consolidating democracy allow us

\footnotetext{
${ }^{1}$ For the overall results of the study, CSI Study, see V. F. Heinrich (2007) CIVICUS, Global Survey of the State of Civil Society, Country Profiles, vol.1 (Bloomfield: Kumarian); V. F. Heinrich and L. Fioramonti CIVICUS, Global Survey of the State of Civil Society, Comparative Perspectives, vol.2 (eds.) (Bloomfield: Kumarian). İçduygu has supervised the survey in Turkey; and throughout the research, engaged with the studies in the other countries. This paper has evaluated the results of this survey and was accepted for publication in January 2011, on the eve of massive revolutionary mobilization in the region.
} 
to rethink the connection between civil society activism and democratisation. Secondlythis paper utilizes the results of the CIVICUS research, recalling Carother's call for moving beyond the reporting of "a chronicle of success stories," in evaluating the relationship between civil society organizations and democracy promotion. ${ }^{2}$ To that end, it focuses on the civil society actors' own experiences and their self-reflexivity, with the goal of critically assessing policy expectations. In fact, the most recent wave of widespread mobilization in the Middle East and North Africa, including Egypt, since late 2010, also indicates a need for rethinking the link between civil society actors and democracy promotion.

The debates in political science have usually started with a broad conceptualization, locating civil society as a terrain outside and autonomous of states and markets. Yet, they have included myriad disagreements over the role of civil society with respect to regime reproduction or transformation. However, when civil society became a celebrated idea in the 1990s, in Western policy circles, this notion of autonomy was adopted less critically, together with a narrower definition, which took into consideration particular sets of organizations as civil society, and expected funding to them to contribute to goals of democracy promotion. On the one hand, the initial assumptions of this research embody the challenges of switching back and forth between these broader and narrower definitions. On the other hand, the responses from civil society actors carry the potential to crystallize a different way of looking at the concept of civil society in the region and elsewhere.

Evaluating civil society actors' own perceptions, we will argue the following: First, with respect to the broader definition, the boundary between state and civil society is not clear-cut. We mean more than various degrees of state intervention in civil society work: states are integral to the shaping of what comes to be known as civil society. In fact, CSOs often cannot measure up to expectations for triggering gradual political liberalization because

\footnotetext{
2 Thomas Carothers, 'A Reply to My Critiques', Journal of Democracy, 13(3) (2002), pp. 3338 .
} 
of their embeddedness in local and international networks of power relations. Second, the narrower definition, usually implicit in the Western policy approach to CSO activism, relates to the impact that CSOs are expected to have, in terms of regime change and social transformation. Yet, CSO actors' self-descriptions challenge these ideas and document the coexistence of multiple and often contradictory values in the CSO field. Thus, this data signals a need to re-evaluate what can reasonably be expected from civil society actors in the capacity in which they are defined. Finally, whereas the three countries in question are host to different regime types and degrees of authoritarianism, civil society actors evaluate their own work in similar ways. This similarity sits uneasily with vast differences in political structures, but foreshadows the need to look at places other than formal CSOs to capture potentials for political and social transformation.

\section{Civil Society and Prospects for Democratization}

Civil society has enjoyed a long and conflicted popularity in the social sciences. ${ }^{3}$ Discussions on civil society organizations were reinvigorated in the 1970s and 1980s as a result of two developments. The first emerged in Latin America in the 1970s and 1980s, when societies were struggling against military regimes. Studies have highlighted the significance of civil society associations outside the purview of the state for dismantling authoritarian rule. ${ }^{4}$ The

\footnotetext{
${ }^{3}$ Georg W. F. Hegel, The Philosophy of Right, trans. T. Knox, (Oxford: Oxford University, 1952), pp. 4-57; Alexis De Tocqueville, Democracy in America, (ed) J.P. Mayer, (transl) George Lawrence, (Garden City, Ny: Doubleday, 1969); Antonio Gramsci, Selections from the Prison Notebooks of Antonio Gramsci, (Eds. \& transl.) Q. Hoare \& G. Nowell (New York: International Publishers, 1971); Karl Marx, 'Contribution to the Critique of Hegel's Philosophy of Law', in: K. Marx \& F. Engels (eds) Collected Works, vol. 3, (New York: International Publishers, 1975a), pp. 8; Karl Marx, 'On the Jewish Question', in: K. Marx \& F. Engels (eds) Collected Works, vol. 3, (New York: International Publishers, 1975b), pp. 153-168.

${ }^{4}$ Guillermo O’Donnell \& Philippe Schmitter, Transitions from Authoritarian Rule: Tentative Conclusions about Uncertain Democracies, (Baltimore, Johns Hopkins University, 1986); John A. Hall, 'In Search of Civil Society', in: John A. Hall (ed.) Civil Society, Theory,
} 
second was the associational mobilization in East European states in the 1980s. The fact that these associational networks peacefully transformed the regimes into liberal democracies made them central to discussions of democratization. ${ }^{5}$ In this experience, civil society came to denote a space out of the reach of and against the state, where citizens engaged with one another and formulated new political strategies. ${ }^{6}$

From the 1990s onwards, many international organizations and Western governments (particularly the United States) have increased funds to CSOs in different parts of the world, for purposes of political liberalization. The interplay between these practices and aforementioned studies has made possible the emergence of lofty expectations from CSOs. They were assumed to consist of networks of formal, voluntary association among diverse groups, excluding primordial, family-related or market-based profitable organizations. ${ }^{7}$ They were to be outside the state, in between the state and the individual, contributing to the responsiveness of the state to citizen demands and citizens' socialization into the political system. ${ }^{8}$ Finally, participation in CSOs was assumed to harbour and promote tolerance, peaceful resolution of conflict, and civility. ${ }^{9}$ Thus policy discussions of democracy promotion combined the broader definition of civil society with expectations of democratization,

History, Comparison, (Cambridge: Polity, 1995), pp. 1-31; Nicos Mouzelis, 'Modernity, Late Development, and Civil Society', in: J.A. Hall (ed.) Civil Society, Theory, History, Comparison (Cambridge: Polity, 1995), pp. 224-249; Alison Brysk, 'Democratizing Civil Society in Latin America', Journal of Democracy, 11(3) (2000), pp. 151-165.

${ }^{5}$ Mihaly Vajda, 'East-Central European Perspectives', in: Keane J (ed.) Civil Society and the State, (London-New York: Verso, 1988), pp. 333-360; Zbigniew Rau, The Reemergence of Civil Society in Eastern Europe and the Soviet Union, (Boulder CO: Westview, 1991).

Wlodzimierz Wesolowski, 'The Nature of Social Ties and the Future of Postcommunist Society: Poland After Solidarity', in: J.A. Hall (ed.) Civil Society, Theory, History, Comparison, (Polity: Cambridge, 1995), pp. 250-277.

${ }^{6}$ Bob Edwards and Michael W.Foley, 'Civil Society and Social Capital Beyond Putnam', The American Behavioral Scientist, 42(1) (1998), pp. 124-139.

${ }^{7}$ Larry Diamond, 'Rethinking Civil Society: Toward Democratic Consolidation', Journal Of Democracy, 5(3) (1994), pp. 4-17; Michael W. Foley and Bob Edwards, 'The Paradox of Civil Society', Journal of Democracy, 7(3) (1996), pp. 38-52.

8 Michael Walzer, 'The Civil Society Argument', in: Ronald Biener (ed.) Theorizing Citizenship, (Albany: SUNY, 1995), pp. 153-174

${ }^{9}$ Adam B. Seligman, The Idea of Civil Society (New York: The Free Press, 1992). 
eschewing critical reflections about both who could be considered part of civil society and what their relations were with existing regimes.

However, over time, scepticism about Western efforts of democracy promotion in the non-West grew. After two decades, civil society, as formulated in the above terms, has "failed to live up to its reputation as a democratic miracle worker." ${ }^{10}$ Therefore, there has been a growing discussion about how civil society can become part of, be influenced by, and build on undemocratic tendencies in the existing political structures. ${ }^{11}$ Scholars have documented how states can employ strategies, oscillating between political liberalization and deliberalization: these include allowing for the establishment of CSOs, whose real power is negligible; co-opting CSOs to create new patterns of obligation; and using these for domestic and external legitimization purposes. ${ }^{12}$

Recent studies on democracy promotion have also revealed tense causal relations between civil society formation and international aid. Aid for democracy promotion can be marred by the credibility and conflicting agendas of the donor governments. ${ }^{13}$ International aid can produce the consequence of increased political control in the aid receiving country

\footnotetext{
${ }^{10}$ Omar G. Encarnación, 'Civil Society Reconsidered', Comparative Politics 38(3) (2006), p 359.

${ }^{11}$ Sheri Berman, 'Civil Society and the Collapse of the Weimar Republic', World Politics 49(3) (1997), pp. 401-430; Ariel Armony, The Dubious Link: Civic Engagement and Democratization (Stanford: Stanford University, 2004); Kenneth M. Roberts, 'Populism, Political Conflict, and Grass-Roots Organization in Latin America', Comparative Politics, 38(2) (2006), pp. 127-147.

${ }^{12}$ Holger Albrecht and Oliver Schlumberger, "Waiting for Godot": Regime Change Without Democratization in the Middle East' International Political Science Review 25(4) (2004), pp.371-392.

${ }^{13}$ Thomas Carothers, 'Choosing a Strategy', in T. Carothers and Marina Ottaway (eds) Unchartered Journey: Promoting Democracy in the Middle East, (Washington D.C.: Carnegie Endowment for International Peace, 2005), pp. 193-208; Peter Burnell and Oliver Schlumberger, 'Promoting Democracy - Promoting Autocracy? International Politics and National Political Regimes', Contemporary Politics, 16(1) (2010), pp.1-15.
} 
because of donor government fluctuation between security and human rights concerns. ${ }^{14}$ The impact of aid may be limited by the fact that donors tend to establish ties with organizations, which bear a resemblance to those at home and speak to donor priorities, but may not necessarily be relevant in the aid receiving countries. ${ }^{15}$

These discussions can be taken one step further if we emphasize the indeterminate nature of the boundary between state and civil society. The difficulty of identifying this boundary is key to understanding the myriad ways in which political power works. ${ }^{16}$ Thus this paper argues for following the ways in which domestic and international states are integral to formally recognized civil society formation. It compares the experiences emerging from three countries in the region to map the myriad ways in which this can happen. The paper makes the case that the broader definition of civil society as outside state, market, and family may actually help the perseverance of existing political arrangements. The data from the survey reveal the different ways in which the assumption of a civil society-state distinction can conceal the construction of civil society arena as part of existing regimes. With respect to the narrower definition, it formulates more realistic expectations based on empirical observation of what civil society actors do achieve. Understanding the link between civil society actors and democratization requires a case-by-case study. This means comparing different patterns of political regulation and control, resource inequalities, and relations with larger grassroots mobilization.

\footnotetext{
${ }^{14}$ Vincent Durac, 'The Impact of External Actors on the Distribution of Power in the Middle East: The Case of Egypt', The Journal of North African Studies 14(1) (2009), pp. 75-90.

15 Amy Hawthorne, 'Middle Eastern Democracy: Is Civil Society the Answer?', Carnegie Papers: Democracy and the Rule of Law Project 44(March) (2004), pp.1-26.

16 Timothy Mitchell, 'Limits of the State: Beyond Statist Approaches and Their Critiques', The American Political Science Review, 85(1) (1991), pp. 77-96; Aradhana Sharma and Akhil Gupta 'Introduction: Rethinking Theories of the State in an Age of Globalization', in: Aradhana Sharma and Akhil Gupta (eds) The Anthropology of the State: A Reader, (Madled, Oxford, Victoria: Blackwell, 1999), pp. 1-41.
} 


\section{Civil Society in the Middle East}

Increased attention to CSOs, in the 1990s and onward, has produced mixed consequences in the Middle East. On the one hand, several actors have benefited from impressive flows of funding. ${ }^{17}$ There has also been a proliferation of associational activity and an initial optimism regarding this development ${ }^{18}$. On the other hand, more critical studies have argued that CSOs have been "embedded in a web of bureaucratic practices and legal codes which allow[ed] those in power to monitor and regulate collective activities." ${ }^{19}$ This state control has had various effects. First, the co-optation of particular segments of civil society actors has made them less willing to exert radicalized pressure on the government. ${ }^{20}$ Yet, their controlled presence has ironically served the purpose of legitimating the existing regime both domestically and internationally ${ }^{21}$. Second, certain "non-political" associations have filled the void left by the state's retreat from welfare provisioning. Finally, using a mixture of legal manoeuvre, media propaganda, and funding selectivity; ruling elites have attempted to control and/or repress politically motivated civil society activism. ${ }^{22}$ These have been vulnerable to governments' wrath, unable to attract popular participation, and dependent on external funding ${ }^{23}$. We propose to formulate these observations not in terms of various patterns of state

\footnotetext{
${ }^{17}$ Hawthorne, 'Middle Eastern Democracy'; Olivier Roy, 'The Predicament of 'Civil Society' in Central Asia and the 'Greater Middle East', International Affairs, 81(5) (2005), pp. 1001.

${ }^{18}$ Saad E. Ibrahim, 'Civil Society and Prospects of Democratization in the Arab World', in: Augustus R. Norton (ed.) Civil Society in the Middle East, vol. I , (Leiden, New York, Köln: E.J. Brill, 1995), pp. 27-54; Augustus R. Norton, 'Introduction', in: Augustus R. Norton (ed.) Civil Society in the Middle East, vol. I (Leiden, New York, Köln: E.J. Brill, 1995).

19 Quintan Wiktorowicz, 'Civil Society as Social Control: State Power in Jordan', Comparative Politics, 33(1) (2000), pp. 43.

${ }^{20}$ Ellen Lust-Okar, 'Divided They Rule: the Management and Manipulation of Political Opposition', Comparative Politics, 36(2) (2004), pp. 159-179.

${ }^{21}$ Holger Albrecht, 'How Can Opposition Support Authoritarianism? Lessons from Egypt', Democratization, 12(3) (2005), pp. 378-398.

${ }^{22}$ Mustapha Al-Sayyid Sa'id, 'Human Rights in the Arab World', in: Sarah Ben Nefissa, Nabil Abd al-Fattah, Sari Hanafi, Carlos Milani (eds) NGOs and Governance in the Arab World, (Cairo \& New York: AUC, 2005), pp. 131-147.

${ }^{23}$ Abd Allah Ahmad Naim, "Human Rights in the Arab World," Human Rights Quarterly, 23(3) (2001), p. 701-732; Sarah Ben Nefissa, (2005) 'Introduction: NGOs and Governance in
} 
intervention in the terrain of CSO activism. Instead, we argue that what comes to be known as civil society, composed of particular CSOs, emerges integral to existing regime types. CSO field does not stand outside states but is shaped as an effect of state structures.

A similar analysis can apply to international connections. On the part of aid giving states, democracy assistance has been part of broader agendas, including the establishment of market economies and implementation of structural adjustment programs. ${ }^{24}$ Thus as official welfare programs were dismantled, development aid to CSOs has shifted toward replacing the gap. Furthermore, international aid for democracy promotion has produced the paradoxical result of political retrenchment: sometimes, authoritarian governments could utilize political activists' connections with donors to brand their demands foreign and suspect. This has been partly due to the declining regional credibility of the donor governments, as in the case of the United States, or the reluctance of donor states to support more politicized activist agendas, as in the case of the European Union. ${ }^{25}$ In overlapping cases, because these donor agencies are perceived as outsiders and in need of local connections, there has been a reasonable likelihood that they communicate with those who already speak their language and are in positions of power. Thus, these connections have either consolidated the power of the privileged by making them into civil society partners ${ }^{26}$ or overemphasized the domestic role of a rather limited range of organizations. ${ }^{27}$ What has been internationally perceived as civil society has been shaped as part of these democracy promotion efforts.

the Arab World', in Sarah Ben Nefissa, Nabil Abd al-Fattah, Sari Hanafi, Carlos Milani (eds) NGOs and Governance in the Arab World, (Cairo \& New York: AUC, 2004), p.5.

${ }^{24}$ Maha Abdelrahman, Civil Society Exposed: The Politics of NGOs in Egypt, (London and New York: I.B. Tauris, 2004), p. 106

25 Thomas Carothers, 'Democracy Assistance: Political vs. Developmental?', Journal of Democracy. 20(1) (2009), pp. 5-19; Richard Youngs, 'Democracy Promotion as External Governance?' Journal of European Public Policy 16(6) (2009), pp. 895-915.

${ }^{26}$ Roy, 'The Predicament of 'Civil Society', p. 1009.

27 Thomas Carothers, Critical Mission: Essays on Democracy Promotion (Washington, D.C, Carnegie Endowment for International Peace, 2004), p. 100-235 
These discussions show the need to throw the net wider and consider the mobilization efforts of the majority of the population, which makes use of tactics outside the conventional modes of liberal civil society ${ }^{28}$. For the Middle East, successful mobilization for more social inclusion, more rights and demands from the state have come not necessarily from legally organized civil society. Instead, ordinary citizens in their everyday life have been practicing creative strategies to defend and improve their life chances against rising inequalities. ${ }^{29}$ The popularity of these more local and community based forms of resistance is visible. ${ }^{30}$ In fact, those efforts, which have been evidently more successful for rising against state retraction of citizen rights, were not necessarily gradual or 'civilized:' they have employed violence as a tool of resistance ${ }^{31}$ and, in the process, have proposed alternative meanings for legitimate political action. ${ }^{32}$ This history and the recent wave of revolutionary mobilization in the region run counter to expectations of non-conflictual change by CSOs.

Thus, there are two further arguments to be made about CSOs in relation to "failures" to induce greater degrees of political liberalization in the region. First, power inequalities, institutional arrangements, and the history of state-society relations determine to a great extent who becomes part of civil society and what they can do. Second, there is a need to rethink what can be expected from CSOs. The history of associational life, the intense debates and indications of what communities desire show that formal CSO activity is only one aspect of

\footnotetext{
${ }^{28}$ Partha Chatterjee, The Politics of the Governed: Reflections on Popular Politics in Most of the World, (New York: Columbia University, 2004).

${ }^{29}$ Asef Bayat, Life as Politics: How Ordinary People Change the Middle East (Stanford, CA: Stanford University Press, 2010)

${ }^{30}$ Asef Bayat, 'Activism and Social Development in the Middle East', International Journal of Middle East Studies, 34(1) (2002), pp. 1-28

31 Larbi Sadiki, 'Popular Uprisings and Arab Democratization', International Journal of Middle East Studies, 32(1) (2000), pp. 71-95.

32 Larbi Sadiki, 'Reframing Resistance and Democracy: Narratives from Hamas and Hizbullah', Democratization, 17(2) (2010), pp. 350-376.
} 
political life and transformation. ${ }^{33}$ Civil society actors can be part of a larger social mobilization that pushes for democratization; however, their very specific formation and embeddedness in existing power relations also make it possible that they help sustain the status quo. Following the experiences and voices of CSO actors allows us to assess these complexities.

\section{A New Source of Evidence: The Civil Society Index (CSI) Study of CIVICUS}

Our analysis of the civil society in Egypt, Lebanon and Turkey utilizes the data from the Civil Society Index (CSI) Study of CIVICUS, ${ }^{34}$ which is a pioneer in its unique methodology and comparative perspective. The CSI Study was a participatory action research that aimed to assess perceptions of civil society in 53 countries around the world between 2003 and $2006 .{ }^{35}$ The analytical framework of the CSI Study starts with a broader definition of civil society than formal associational life. It starts with a working definition civil society as "the arena outside of the family, the state and the market where people associate to advance common interests." Yet it also acknowledges that, in reality, the boundaries between these spheres are not clear-cut. This paper makes use of this observation and, in the words of formally recognized civil society actors, evidences the need for either reassessing expectations towards them or rethinking the meaning of civil society activism.

The CSI Study assesses perceptions of civil society utilizing the "Civil Society Diamond," composed of four interrelated dimensions: structure, environment, values, and

${ }^{33}$ Peter Gubser, 'The Impact of NGOs on State and Non-State Relations in the Middle East',Middle East Policy 9(1) (2002), pp. 140-141

${ }^{34}$ For details, see the organisation's webpage, https://www.civicus.org/download/CIVICUS'\%20Members\%20List-

\%20December\%202011.pdf

${ }^{35}$ Volkhart F. Heinrich, CIVICUS, Global Survey of Civil society, Country Profiles, vol. 1, (Bloomfield; Kumarian, 2007); Volkhart F. Heinrich and Lorenzo Fioramonti, CIVICUS, Global Survey of the State of Civil Society, Comparative Perspectives, vol. 2 (Bloomfield, Kumarian, 2008). 
impact. These dimensions, in turn, aggregate a number of sub-dimensions: the structure is measured by the breadth and depth of citizen participation, diversity within civil society, and level of organization, interrelations, and resources. The environment evaluates relevant formal political, economic, social and cultural factors, and attitudes of public and private sector actors. The values dimension examines the extent to which CSOs promote and practice principles of democracy, transparency, tolerance, non-violence, gender equity, poverty eradication, and environmental sustainability. The impact looks at CSOs influence on public policy, their ability to hold state and private corporations accountable, and the extent to which they respond to social interests, empowers citizens and meets societal needs. ${ }^{36}$ If a dimension gets a score of 3 , this means the country in question has achieved the ideal for that dimension. If the score is 0 , this shows an absolute failure.

These scores, offering a unique comparative data to be incorporated in the literature on civil society in the Middle East, provide the backbone for our analysis. The scoring exercise of the CSI Study and its resulting "CSI Diamond" is only one part of a larger analysis of civil society practices. They are the aggregated result of population surveys, aiming to measure the level and quality of recognition of and participation in civil society; surveys among CSO actors in different regions in each country; group discussions in these regions with the same stakeholders; interviews with experts in the field as well as media research and secondary literature review. In each country, the scoring process utilized the method of citizen jury, a role undertaken by National Advisory Groups (NAG). First, after reviewing the entire data collected, the members of the NAGs scored individually each of the seventy-four indicators, leading to sub-dimensions and dimensions. Second, the distribution of the scores were evaluated and, for each case, where the variation among members' scoring exceeded 1 point,

${ }^{36}$ ibid.; Volkhart F. Heinrich and Camen Malena, (2008) 'How to Assess the State of Civil Society Around the World?', in: Volkhart F. Heinrich and Lorenzo Fioramonti (eds) CIVICUS, Global Survey of the State of Civil Society, Comparative Perspectives, vol. 2, (Bloomfield: Kumarian, 2008), pp. 3-18. 
the team reviewed the evidence collectively, held discussions, and went through a re-voting. The indicators were then aggregated; combined into sub-dimensions and dimensions.

The CSI Study provides a rare opportunity to hear the voices of social actors actually located in these contexts. Providing them with a common ground for evaluating themselves, the CSI Study has been successful in bringing together the opinions of various civil society actors and stakeholders who do not always "find common ground, due to irreconcilable differences in values, interests, and strategies." ${ }^{, 37}$ It is within this context that incorporation of civil society actors into the CSI Study is critical. The project's direct engagement with stakeholders is crucial for the purposes of this paper because particularly in the cases of Egypt, Lebanon, and Turkey, they are diverse and the field bears the brunt of parochialism and internal fragmentation.

Given the "experimental character" of the CSI Project, ${ }^{38}$ this current article has a number of limitations. The first has to do with the use of quantitative data for country comparisons. Although quantitative information is useful in recapitulating complex settings in easily readable scores, at the same time, it also risks reducing the diverse and multifaceted aspects of civil society to simple numbers. Furthermore, the quantification is based on actors' self-assessments, without their own comparison with different contexts. This paper attempts to overcome the risk of oversimplification by giving ample room to voices emerging from surveys and discussion groups. It also attempts to establish a comparative framework to capture the nuances of self-assessments with respect to different regime types and state strengths. Second, it is crucial to bear in mind that more in-depth single country cases would reveal further complexities for each case alone. The paper attempts to strike a balance between general assessment, comparison, and case-by-case analysis. Finally, some definitional concerns should be taken into consideration. The CSI Study is informed by the

\footnotetext{
${ }^{37}$ Heinrich, CIVICUS, Global Survey of Civil society, p.11

${ }^{38}$ Heinrich and Fioramonti, CIVICUS, Global Survey of the State of Civil Society, p. xxxii
} 
broader definition of civil society as outside of state, family and market; but its evaluation has been somewhat restricted to a narrower focus on CSOs and assumptions regarding their potential for inducing democratization. While this approach is probably useful and necessary for the comparative nature of the study, it has shortcomings in its ability to portray informal mobilization efforts as well as other types of impact. Our elaboration of the CSI Study in the three country cases in the region benefits from the unique strengths of the given data set, but it also uses the shortcomings of these definitions as they emerge from CSO actors' acknowledgements, in order to address the multifaceted nature of the civil society arena.

\section{Mapping Civil Society in Egypt, Lebanon, and Turkey}

This section maps the characteristics of civil society in Egypt, Lebanon, and Turkey, based on the responses of survey participants. The analysis first takes up structure and environment together for each country and situates them in their recent history. It discusses comparatively the participants' self-evaluations with respect domestic states, international donor states, and societies. Then, utilizing this history, the remaining two dimensions, value and impact, are analyzed. The contrasts between values and impact are drawn out and situated in a discussion of other forms of activism.

\section{Disabling Structures and Environments}

In all three countries, CSO numbers have increased visibly in the recent decades. According to official sources, there are around 85,000 nationally operating CSOs in Turkey. ${ }^{39}$ In Egypt, the number of registered associations reaches 14,000 , even though a major portion is dormant. ${ }^{40}$ In Lebanon, there are about 6000 CSOs even though those active on a regular basis

\footnotetext{
${ }^{39}$ See Ministry of Interior figures at http://www.dernekler.gov.tr (accessed 10 July 2010).

${ }^{40}$ Hawthorne, 'Middle Eastern Democracy', p.9
} 
is estimated to be a lower figure. ${ }^{41}$ Yet these numbers do not reflect the political elite's power over the formation and maintenance of civil society activity. The self-evaluation of the CSO actors in all three cases shared an emphasis on the negative quality of their relations with domestic states as well as society. The results were more ambiguous with respect to international donors. Combining these assessments with the historical development of civil society in these contexts will reveal the empirical impossibility of conceptualizing distinct spheres of social and political activity.

Table 1: Evaluations of Structure and Environment

\begin{tabular}{|l|c|c|c|c|c|c|c|c|}
\hline Countries & Structure & $\begin{array}{c}\text { Deviation } \\
\text { from } \\
\text { Worldwide } \\
\text { average }\end{array}$ & $\begin{array}{c}\text { Deviation } \\
\text { from } \\
\text { Worldwide } \\
\text { median }\end{array}$ & Ranking & Environment & $\begin{array}{c}\text { Deviation } \\
\text { from } \\
\text { Worldwide } \\
\text { average }\end{array}$ & $\begin{array}{c}\text { Deviation } \\
\text { from } \\
\text { Worldwide } \\
\text { median }\end{array}$ & Ranking \\
\hline Egypt & 1.20 & 0.23 & 0.20 & 10 & 1.10 & 0.51 & 0.40 & 14 \\
\hline Lebanon & 1.50 & -0.07 & -0.10 & 7 & 1.40 & 0.21 & 0.10 & 12 \\
\hline Turkey & 0.90 & 0.53 & 0.50 & 13 & 1.40 & 0.21 & 0.10 & 12 \\
\hline $\begin{array}{l}\text { Worldwide } \\
\text { average }\end{array}$ & 1.43 & & & & 1.61 & & & \\
\hline $\begin{array}{l}\text { Worldwide } \\
\text { median }\end{array}$ & 1.40 & & & & 1.50 & & & \\
\hline
\end{tabular}

Calculated from data in (Heinrich, 2007)

Highest score: 3 ; lowest score: 0

Total number of countries $=45$

Please note there were 13 discrete scores for structure and 18 for environment.

The chart above summarizes the scores obtained for structure and environment in each case. One the one hand, while the numbers in comparison with the rest of the population indicate weaker structures (for Egypt and Turkey) and environment (for all three), there is considerable variation among the three. It is also significant that participants in Egypt evaluated their structure in more favourable terms than those in Turkey, despite the more visible state role in the formation of CSOs in the former. While this was a result of selfreflexivity without broader regional comparison, it can also be seen as evidence of embeddedness in existing political systems. The discussion below will compare consecutively the participants' responses in terms of state actions, international donor impact, and degree of

\footnotetext{
${ }^{41}$ Calculated from CIVICUS Civil Society Index Report for Lebanon, (Beirut: IMTI), p. 26
} 
proliferation in society. It will show that both local and international states are very much part of the way CSOs are shaped. It will also reveal the relative absence of proliferation within the population.

The surveys confirm a problematic oscillation on the part of the states between liberalization and deliberalization ${ }^{42}$ with definitive impact on CSOs. In Turkey, we can talk about a historically strong state ${ }^{43}$ especially true in areas such as the "correct" place of religion in public life, minority rights, and Kurdish identity politics. Today, the Turkish regime, on the one hand, is characterised as a consolidating democracy, with more potential for increasing and widening the types of CSOs. On the other hand, we are witnessing the rise of a new wave of authoritarianism by the governing Justice and Development party. In the Egyptian case, there are two aspects of the authoritarian regime to which one needs to pay attention. First, the stronghold of the state on public life has had marked impact on both who could survive as CSOs and do more than exist on paper. Second, whereas the state actors have refused to democratize, they have been very adamant in consolidating economic liberalization. ${ }^{44}$ Thus, CSOs have also been shaped in response to state's declining welfare provisioning. In Lebanon, the regime has been characterized by its sectarian nature: this is also a central character of the CSO field. Historically called an example of consociational democracy, ${ }^{45}$ the unequal and exclusionary nature of Lebanese citizenship has led to state's

\footnotetext{
${ }^{42}$ Albrecht and Schlumberger, "Waiting for Godot"

${ }^{43}$ Metin Heper, The State Tradition in Turkey, (Walkington: The Eothen Press,1985); Metin Heper, 'Strong state as a problem for the consolidation of democracy: Turkey and Germany compared'. Comparative Political Studies, 25 (1992), pp. 169-194.

44 Raymond A. Hinnebusch, 'Liberalization without Democratization in "Post-Populist" Authoritarian States: Evidence from Syria and Egypt' in N.A. Butenschon, U. Davis, and M. Hassassian (eds). Citizenship and the State in the Middle East: Approaches and Applications, (New York: Syracuse University Press, 2000), pp. 123-145.

${ }^{45}$ Arendt Lijphart, Democracy in Plural Societies: A Comparative Exploration (New Haven: Yale University Press, 1977)
} 
collapse during the $1975-1990$ civil war. ${ }^{46}$ The government continues to be marked by instability and frequent collapse. These features also mark the inequalities in the CSO field. In all countries, the consolidation of the CSO field has been integral to state strength and regime types, in different ways.

Civil society activities "have flourished in Turkey with democratization and rapid social mobilization in the aftermath of World War II." ${ }^{, 47}$ This trend has again marked the social scene since the 1990 s, after a repressive period following the 1980 military coup. ${ }^{48}$ However, participants observed that overall relations with the state remained limited or hostile. $^{49}$ The state was described as having become the most powerful actor in the political, economic, social, and cultural spheres. On the one hand, since 1999, legislative reforms have lifted a number of restrictions on associations. The most important of these is the new Law on Associations, which reduces the possibility of state interference and partly removes limitations on the establishment of associations on the basis of race, ethnicity, religion, sect, and region, or any other minority group. On the other hand, a 2005 addendum continues to impose restrictions on the registration of associations whose names and/or objectives are considered contrary to the Turkish Constitution. As a result, associations whose objectives include promoting a certain cultural identity or particular religion are still not able to register. Although recent legal changes indicate a positive upward trend, participants complain of frequent interference from government authorities; restricted access to government funding;

\footnotetext{
${ }^{46}$ Rania Maktabi, 'State Formation and Citizenship in Lebanon: The Politics of Membership and Exclusion in a Sectarian State.' in N.A. Butenschon, U. Davis, and M. Hassassian (eds). Citizenship and the State in the Middle East: Approaches and Applications, (New York: Syracuse University Press,2000), pp. 146-178

${ }^{47}$ Ersin Kalaycioğlu, 'State and Civil Society in Turkey: Democracy, Development, and Protest', in: A.B. Sajdoo (ed.) Civil Society in the Muslim World, (London: I.B. Tauris, 2002), p. 247.

${ }^{48}$ Ömer Faruk Gençkaya, Ruşen Keleş and Yasushi Hazama, Aspects of Democratization in Turkey, (Tokyo: Institute of Developing Economies, 1999), pp. 53-97; Sefa Şimşek, 'New Social Movements in Turkey since 1980', Turkish Studies 5(2) (2004a) pp. 111-139.

${ }^{49}$ CSI Turkey, CIVICUS Civil Society Index Report for Turkey, ed. Filiz Bikmen and Zeynep Meydanoglu (Istanbul: Tusev, 2006), p. 66.
} 
and, at best, limited dialogue with state officers. ${ }^{50}$ These complaints, even though couched in the language of a binary between state and civil society, reveal the dependence of the formation and consolidation of CSOs on state policies.

In Egypt, even though there was a hesitant liberalization in the 1970s, the regime eventually suppressed political activism. Similarly, after an initial relaxation in the 1980s, the Mubarak regime severely curbed CSOs. Survey participants emphasized that due to the overbearing presence of the state, the persistence of the emergency law and corruption, as well as the poor skills of public officials, the political context was restrictive. ${ }^{51}$ These observations reflect the incremental power that the Ministry of Social Affairs (MOSA) has wielded over CSOs since its establishment in 1939. Over the years, ministry has required CSOs to register with the ministry, refused license applications on vague rationale such absence of need; merged CSOs in similar areas; and exercised control over board membership and decision making. ${ }^{52}$ In 2002 legal changes regarding civil society, control over CSO activities as well as the types of funds they can accept has become even harsher. ${ }^{53}$ In the survey and discussions, majority of the stakeholders did not have negative assessments of MOSA registration requirements, but the participants also acknowledged that this was mainly due to the relative absence of human rights and religious organizations among them ${ }^{54}$. The discrepancies in the experiences reveal state impact on CSO formation and comparative strength. Furthermore, there is another pattern of organic ties between CSOs and the state: the government has been establishing its own organizations in fields such as human rights, where it perceives independent CSOs as a threat. These organizations give the MOSA a pretext not

\footnotetext{
${ }^{50}$ ibid, p. 71-72

${ }^{51}$ Heinrich, CIVICUS, Global Survey of Civil society,p.118

52 Abdelrahman, Civil Society Exposed, p. 127-131

${ }^{53}$ The trend appears to continue in the 2012 draft law in preparation.

${ }^{54}$ CSI Egypt, CIVICUS Civil Society Index Report for Egypt (Cairo: CDS, 2006), p.48.
} 
to register other independent organizations in the same fields ${ }^{55}$. Thus state power in Egypt has given rise to a particular set of legal CSOs and curbed and rendered precarious those it considers a threat to the establishment

In the case of Lebanon, the sectarian organization of the political structure and the state's absence from welfare provisioning are determinants in CSO structure. Associational mobilization in Lebanon is mainly organized along communitarian lines. In other words, CSOs are likely to repeat, rather than undercut, existing divisive patterns of the political regime. During the civil war (1975-1990), much of this activism was generated in the fields of welfare provisioning and emergency relief. This type of associational mobilization occurred because the Lebanese state has never been a significant presence for the needs of communities. In addition, the stakeholders point to weak institutionalization and exemplify this in terms of the absence and weakness of resource centres, information services, technical assistance programs, and inactivity in self-regulation. ${ }^{56}$ They also emphasize the history of political instability and widespread corruption. The piecemeal nature of the Law on Associations leaves too much to the discretion of public officials in their treatment of CSOs. ${ }^{57}$ As in Egypt and Turkey, the state is attributed a series of negative characteristics that shape the CSO field. Yet, in this case, it is not because it is overarching, but, rather, the problem is that the social state is absent and law making displays a makeshift nature. These result in the consolidation of certain organizations and rendering of others vulnerable. Furthermore, the associational life along sectarian lines repeats the patterns of the political regime, and therefore, its problems.

In the shaping of civil society structures, international actors have also played a significant role. In the case of Turkey, the prospect of EU membership has been pivotal in two

55 Julia Pitner, 'NGO's Dilemmas', Middle East Report Online 214 (Spring 2000). http://www.merip.org/mer/mer214/214_pitner.html

\footnotetext{
${ }^{56}$ Heinrich, CIVICUS, Global Survey of Civil society,p. 222

${ }^{57}$ CSI Lebanon, CIVICUS Civil Society Index Report for Lebanon (Beirut, 2006), p.77.
} 
ways. First, the recent legal changes carry the visible mark of EU-based harmonization efforts. During the last decade, the Turkish government had to prepare itself to meet the Copenhagen Criteria, which require institutions for democratic governance, as well as mechanisms that ensure the protection of human rights. Yet this process is marked by limitations and ambiguities due the fact that this is an external anchor. ${ }^{58}$ Second, associations continue to receive an overwhelming share of EU assistance and support. The EU-originated support has had palpable impact on the overall democratization process. The survey results show that stakeholders place great importance on EU support. Yet, they also criticize the cumbersome, bureaucratic and unclear nature of aid competition. ${ }^{59}$ The competition is likely to structure an oligopolistic CSO field, biased toward larger and more professionalized organizations with capacity for dealing with large bureaucracies.

Egypt has been akin to a laboratory of the Middle East for external aid. Even though the study showed that reliance on international donors was not widespread, this aid is often the only source of finance for human rights organizations and some development CSOs. ${ }^{60}$ In fact, in recent years USAID has poured millions of dollars into Egypt, with the goal of bolstering civil society. Yet, the goal was not only to promote democracy, but also to encourage and broaden neo-liberal agendas of economic restructuring. ${ }^{61}$ Moreover, a much bigger chunk of US aid has gone to the military, shoring up the authoritarian capacity of the state. After the signing of the Euro-Mediterranean Partnership in 1995, the EU has provided

\footnotetext{
${ }^{58}$ Thomas Diez, Apostolos Agnantopoulos and Alper Kaliber 'File: Turkey, Europeanization and Civil Society Introduction', South European Society and Politics 10(1) (2005), pp. 1-15; Ahmet Içduygu, 'The Anatomy of Civil Society in Turkey: Toward a Transformation', in: F. Keyman (ed.) Remaking Turkey (Lanham: Lexington, 2008), pp. 179-197.

${ }^{59}$ CSI Turkey, 2006, p. 19

${ }^{60}$ CSI Egypt, 2006, p. 37

${ }^{61}$ Sheila Carapico, 'NGOs, INGOs, GO-NGOs and DO-NGOs: Making Sense of NonGovernmental Organizations', Middle East Report 214 (Spring 2000), p.214; Hawthorne, 'Middle Eastern Democracy'.
} 
support for projects of civil society, economic liberalization and good governance. ${ }^{62}$. Yet, in both cases, the aid has been couched in concerns of regional security and fears of Islamist politics. This has meant that funding usually excluded religious associations and donor states remained less vocal in their protests when the state cracked down on mobilization, calling it Islamist. In the surveys for this particular study, religious associations and human rights organization were not represented sufficiently, a fact to which participants attributed the relative silence on complaints about the political environment. This silence is telling in its distance from the diversity of actors, who coalesced in the recent revolutionary mobilization, toppling Mubarak.

In Lebanon, from the end of the civil war in 1990 onwards (and especially after the recent Israeli bombardment in 2006), CSOs have continued the work of emergency relief. These CSOs are also beneficiaries of the US aid. The US government has had multiple goals: rebuilding local communities, reaching partners more reliable than the weakened government, and supporting service CSOs as a counterweight to Islamic networks. ${ }^{63}$ The regional consultations show that most of this aid goes to large CSOs with international networks. ${ }^{64}$ As a result, CSOs reflect domestic political arrangements as well as international agendas. First, many CSOs in Lebanon fill the vacuum of state welfare and are shaped in accordance with the demands of this work. Second, other donor states play an important role in the ways in which civil society activism takes shape; selecting particular CSOs over others, lending some more international visibility and legitimacy than others.

The analysis so far reveals that the relationship between democracy promotion, civil society formation, and political change is contingent upon several key structural elements. Whereas the CSO actors talked about the degree of receptiveness or hostility on the part of

\footnotetext{
${ }^{62}$ Durac, 'The Impact of External Actors', p. 80

${ }^{63}$ Hawthorne, 'Middle Eastern Democracy', p. 15.

${ }^{64}$ CSI Lebanon, 2006, p. 46
} 
domestic states, there is more to be said than varying degrees of state interference. The range, type, and power of CSO formation is integral to state policies. International donors also shape the survival of CSOs through their selectivity. Then the question becomes; how do stakeholders perceive their own degree of pervasion in society, given these conditions? Participants acknowledge problems in this area. In Egypt and Turkey, the problem is limited proliferation. In Lebanon, there is more participation, but its characteristics appear to repeat and not necessarily overcome existing divisions in politics.

In Turkey, active formal civic participation in CSO-based activities is still quite limited, ${ }^{65}$ with a membership figure approximately 10 percent of citizens. ${ }^{66}$ Furthermore, this number includes enforced membership in professional organizations and state-related community organizations. ${ }^{67}$ Thus, caution should be exercised in crediting the legal changes and the increasing number of CSOs with an expansion and deepening of citizen participation. The survey findings indicate that CSO membership rates are particularly low for women, the poor, minorities, and rural populations. ${ }^{68}$ It was believed that the primary causes for this are persistent and severe socio-economic conditions, ethnic conflict, and the negative discourses and practices concerning the freedom of association. ${ }^{69}$ These observations point to how the shaping of CSO work as part of institutional constraints can also limit their ability to generate the kind of mass participation necessary for political transformation.

In Egypt, CSOs include religious organizations, as well as business associations, labor unions, and service-oriented NGOs. Despite this diversity, the membership rate is rather low.

${ }^{65}$ Sefa Şimşek, 'The Transformation of Civil Society in Turkey: From Quantity to Quality', Turkish Studies 5(3) (2004b), pp. 46-74.

${ }^{66}$ See Ministry of Interior figures at http://www.dernekler.gov.tr/index.php?option=com_content\&view=category\&layout=blog\&i $\mathrm{d}=52 \&$ Itemid=12\&lang=tr; last accessed July 10, 2010

${ }^{67}$ Içduygu, 'The Anatomy of Civil Society in Turkey'.

${ }^{68}$ CSI Turkey, 2006, pp. 48

${ }^{69}$ Heinrich, CIVICUS, Global Survey of Civil society,p.398 
Active membership and leadership seem confined to a small segment of the society, insulated from the widespread problems of the majority. The stakeholders described the leadership in terms of "older men, with high socioeconomic status." Women, rural populations, and the poor are not members, ${ }^{70}$ but are more likely to be at the receiving end of programs. The participants attributed this to the lack of values such as trust, public spiritedness, and interest in collectivity. ${ }^{71}$ Yet we can also emphasize the way in which this pattern repeats some of the power inequalities in the country. CSOs cannot, by themselves, be agents of change because they may be shaped as part of networks of privilege.

The survey data from Lebanon revealed widespread community help in the absence of a welfare state. Participants indicate more support from the community and more voluntary activism than in Egypt or Turkey. ${ }^{72}$ Mostly, this means charitable giving and volunteer work. Furthermore, despite limited communication, the survey indicated that co-operation and joint campaigns on particular issues were more common than in the other two cases, even if they were not sustained. ${ }^{73}$ The qualifying factor in the case of Lebanon is the pervasiveness of sectarian divisions. In this case, there is a stronger tradition of more widespread community activism. Yet this does not always mean the proliferation of non-sectarian norms.

From these observations one identify three themes. First, the participants describe either an over-powerful state with restrictive regulation, or a weak state with piecemeal regulation. Despite variations in regimes and state action, there is a similar characterization of access to and funding from the government: not everyone has an equal chance to receive these. We can actually say more: many organizations are shaped as part of and in response to existing state structures and policies. State structures and regime types impact on what types of organizations are likely to have a more than precarious existence - such as service CSOs,

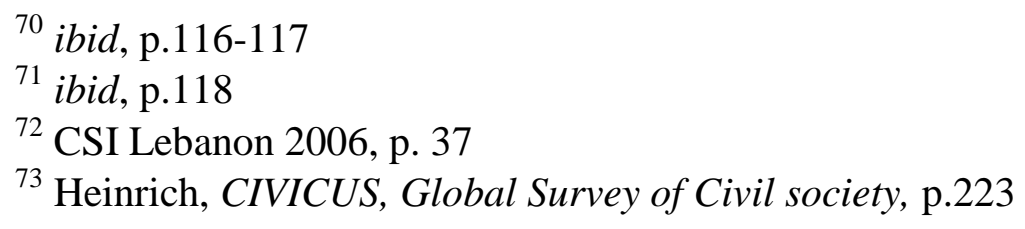


"non-political" associations, or organizations in favour of the government, rather than "political" organizations, more vocal in criticizing existing regimes. Second, funding choices of international donor states also contribute to the construction of the CSO scene. The kinds of issues pushed for, the types of projects devised speak to donor state choices. These choices do not always coincide with societal priorities in these countries, but result in CSOs, somewhat isolated from the majority of the population. The third related theme has to do with the low levels of participation and possible undertones of patronage relations. In other words, there is a danger that CSOs repeat some of the regime patterns and inequalities present in these contexts.

This analysis of the self-assessment of CSO actors shows the productivity of emphasizing everyday complexities and beginning with the indeterminate boundaries between civil society and state. First, this allows us to recognize possible limitations in civil society work to initiate gradual democratization. While acknowledging and thinking about ways to support the important work done by these organizations, this approach reveals how civil society networks are never established on a blank slate. The structure and activities of many CSOs reflect the range of possibilities determined by existing power inequalities. Second, by focusing on these complications, it becomes possible to find reasons why some associational networks do not reach a wider population at best and can end up contributing to the survival of unpopular regimes at worst. ${ }^{74}$ Third, rethinking the meaning of "registered," "official," or "formal" CSOs in terms of their organic ties with the states — whether domestic or international - paves the way for including an analysis of other networks. The characteristics we attribute to CSOs can also be found in informal networks. Recognizing the roles performed by activism outside the purview of the official gaze can bring us closer to capturing everyday politics.

\footnotetext{
${ }^{74}$ Roy, 'The Predicament of 'Civil Society',
} 


\section{Ambivalent Values and Impact}

This section will explain the stakeholders' assessment of the values they practice in CSOs and their impact. The results suggest a discrepancy between the values the participants hold and their everyday experiences. As the figures in Table 2 show, these lead to the emergence of some of the lowest scores worldwide (especially for Egypt and Lebanon), while, at the same time, internal comparison shows high scores for values. Using these results, we will critically assess assumptions underlying the survey, which occasion a switch back and forth between broader and narrower conceptualizations of civil society, both in terms of the range of participants and expectations of civic values. The discrepancy between values and practice, emerging from the self-perceptions of CSO actors, is evidence for the need to challenge a blind faith in two types of causal relationships: one between associational life and the flourishing of particular values, and another between CSOs and political transformation.

Table 2: Evaluations of Value and Impact

\begin{tabular}{|l|c|c|c|c|c|c|c|c|}
\hline Countries & Values & $\begin{array}{c}\text { Deviation } \\
\text { from } \\
\text { Worldwide } \\
\text { average }\end{array}$ & $\begin{array}{c}\text { Deviation } \\
\text { from } \\
\text { Worldwide } \\
\text { median }\end{array}$ & Ranking & Impact & $\begin{array}{c}\text { Deviation } \\
\text { from } \\
\text { Worldwide } \\
\text { average }\end{array}$ & $\begin{array}{c}\text { Deviation } \\
\text { from } \\
\text { Worldwide } \\
\text { median }\end{array}$ & Ranking \\
\hline Egypt & 1.50 & 0.37 & 0.40 & 12 & 1.00 & 0.66 & 0.60 & 16 \\
\hline Lebanon & 1.80 & 0.07 & 0.10 & 8 & 1.50 & 0.16 & 0.10 & 12 \\
\hline Turkey & 1.30 & 0.57 & 0.60 & 14 & 1.30 & 0.36 & 0.36 & 14 \\
\hline $\begin{array}{l}\text { Worldwide } \\
\text { average }\end{array}$ & 1.87 & & & & 1.66 & & & \\
\hline $\begin{array}{l}\text { Worldwide } \\
\text { median }\end{array}$ & 1.90 & & & & 1.60 & & & \\
\hline
\end{tabular}

Calculated from data in (Heinrich, 2007)

Highest score: 3; lowest score: 0

Total number of countries $=45$

Please note there were 14 discrete scores for values and 17 for impact.

In Turkey, even though CSOs increasingly promote values such as democracy, transparency, non-violence, and gender equity, a majority of participants acknowledged weak internal practice. CSOs perceived themselves to play an important role in promoting environmental sustainability and democracy. They also saw themselves successful in affecting 
policies regarding human rights, especially those related to freedom of expression. ${ }^{75}$ Yet, incidences of intolerance within civil society were quite common, in particular with reference to the "growing nationalist movement, mobilization around the headscarf issue, and tensions around ethnic and religious minorities." ${ }^{, 76}$ In Egypt, the dimension of values was the highest scoring one for the country. The participants claimed "an internal propensity to practice core values such as tolerance, democracy, gender equity," and charities practiced non-violence, tolerance, and poverty eradication. However, overall Egyptian CSOs were seen more successful in rallying support for "apolitical" values than for "politically sensitive ones." Lebanon, as in the other cases, the highest score was for values because the participants attested to "strong efforts to promote and practice ... tolerance, non-violence, gender equity, poverty eradication and environmental sustainability." ${ }^{78}$ In both cases, however, there were also strong indications that values such as democracy and tolerance were not always practiced internally.

Each survey shared an emphasis on limitations of impact. In Turkey, civil society was seen weakest in holding the state and private sector accountable and responding to social problems, such as unemployment, inflation, and corruption. ${ }^{79}$ On the other hand, civil society's impact is increasingly becoming more visible. There is a growing list of examples of how CSOs meet various social needs, especially concerning education, human rights, the poor and women, and of civil society's advocacy success on policy issues. In Egypt, after the government shift to neoliberal economic policies, the government has incrementally stripped its social protection mechanisms. Many of the CSOs have moved into the vacuum thus

\footnotetext{
${ }^{75}$ CSI Turkey, 2006, p. 94

${ }^{76}$ Heinrich, CIVICUS, Global Survey of Civil society, p.400

77 ibid, p. 118

${ }^{78}$ ibid, p.224

${ }^{79}$ ibid, p.402
} 
created. ${ }^{80}$ Hence, there is significant impact in the field of welfare provisioning. This is coupled with the activities of associations increasingly vocal on human rights issues. However, participants saw their potential role in changing aspects of the existing political regime as rather limited. ${ }^{81}$ In Lebanon, too, CSOs saw most of their impact in welfare provisioning. ${ }^{82}$ Yet, the state's weakness in terms of welfare provisioning did not translate into receptiveness to civil society influence. CSO actors considered themselves limited in terms of influencing and monitoring the government and its policies. While CSO actors raised their voice on specific policies, the majority was dissatisfied with their own performance ${ }^{83}$.

The discrepancy between values endorsed and social impact as well as ambiguities regarding civic internal practice require further deliberation. One reason for increasing CSO demands for democracy, tolerance and equity is related to international donor impact. For the case of Turkey, European integration has been directly linked to increased vocalization of these values. Similarly, in Egypt and Lebanon, both the USAID and the EuroMed aid have specifically targeted civil society projects promoting such issues. Yet in this support, there were two qualifiers: first, donors have chosen to work with a limited range of associations, which were not necessarily pervasive in these countries. Second, the same sources also devoted equal, if not more, attention to establishment of market economies, with devastating consequences for the societies. These contradictions can go a long way in explaining low participation and limited impact. Another explanation lies in the formal, registered nature of many of these CSOs. Indeed, in these countries there are all kinds of informal networks, which are not CSOs. There are also types of associational activities not condoned by states domestic or international. As the recent struggles reveal, in order to capture potential for and direction of social and political change, more attention has to be paid to these formations.

\footnotetext{
${ }^{80}$ ibid, p.119

${ }^{81}$ CSI Egypt, 2006, p. 56

${ }^{82}$ Heinrich, CIVICUS, Global Survey of Civil society, p.225-226

${ }^{83}$ CSI Lebanon, 2006, p. 106
} 
Particularly in the last two decades, most influential activism in Turkey involved new social movements — such as feminism, environmentalism, human rights activism, religious fundamentalism, and cultural, ethnic and sexual preference movements — rather than coming from the ranks of the established mobilization of trade unions, students, and classical nationalist activism. ${ }^{84}$ There have been vibrant discussions among secularist, Islamist and nationalist circles. ${ }^{85}$ While these new types of activism are different from their older counterparts, some are criticized as being primordial and/or "undesirable." The narrower conceptualization of civil society, ostensibly utilized for funding purposes, sees some of their characteristics as contradictory to "modern" or "Western" values.

Relevantly, the cases of the Islamist and Kurdish movements are illustrative. Both movements have been fairly successful in the advocacy of democratization and human rights. The importance of the Human Rights Association (IHD), which is mostly related with the Kurdish movement, and the Organization of Human Rights and Solidarity for Oppressed People (Mazlumder), which collaborate their efforts in various agendas, needs to be mentioned. The relationship of the concepts of civil society, democracy, and human rights to the Kurdish movement in Turkey is strained by official and widespread perceptions that locate it as a violent, separatist ethnic movement. The relationship between civil society, democracy, human and women's rights on one side and the Islamist movement on the other is even more complex. Some of this activism ends up emphasizing "religious patriarchy" despite increasing the visibility of Islamist women in politics. ${ }^{86}$ Yet, as Kadığlu ${ }^{87}$ notes, "while some Islamic

\footnotetext{
${ }^{84}$ Şimşek, 'New Social Movements'

${ }^{85}$ Nilüfer Göle, 'Authoritarian Secularism and Islamist Politics: The Case of Turkey', in: A.R. Norton (ed.) Civil Society in the Middle East, vol. I, (Leiden, New York, Köln: E.J. Brill, 2001), pp. 17-44; Ayşe Kadığlu, 'Civil Society, Islam and Democracy in Turkey: A Study of Three Islamic Non-Governmental Organizations', The Muslim World 95(1) (2005), pp. 23 41; Fuat Keyman and Ahmet Içduygu, 'Globalization, Civil Society and Citizenship in Turkey: Actors, Boundaries and Discourses', Citizenship Studies 7(2) (2003), pp. 219-234. ${ }^{86}$ Ayşe Güneş Ayata and Fatma Tütüncü, 'Party Politics of the AKP (2002-2007) and the Predicaments of Women at the Intersection of Westernist, Islamist and Feminist Discourses in
} 
organizations display closed, absolutist and authoritarian tendencies, others point to the possibility of a convergence among civil society, Islam and democracy." In the recent years, there has been an increasing polarization of the Turkish politics along binary definitions of nation, state, secularism, and democracy. ${ }^{88}$ This is a fascinating process in which actors more likely to be outside the purview of officially recognized CSOs are contributing to the flourishing of civil society.

In the case of Egypt, casting the net wider allows us to look at four nodes of activism. The first is the centrality of community based and familial networks to associational life. Singerman ${ }^{89}$ argues that the mainstream Western conceptualization, also adopted by the secular elite in the country, misses the significance of such networks and makes generalizations about depoliticized and individualistic values. Within this context, neighbourhood based campaigns against problems such as industrial pollution and state demolition of districts reflect grassroots opposition to existing inequalities in the country ${ }^{90}$. Second, even more visible activism emerges from the ranks of social Islam, "which has become the most pervasive phenomenon in the region." ${ }^{91}$ Islamist mobilization in general and, specifically, Muslim Brotherhood has shown a remarkable proliferation and transformation since its inception, lately entering into collaborations with other activists to achieve more political power. ${ }^{92}$ Third, since 2004 , there has been a visible increase in labour strikes, supporting one another across regions. This has been in response to state acceleration of privatization of public enterprises, as a result of which many workers began losing their

Turkey’ British Journal of Middle Eastern Studies 25(3) (2008), pp. 363-384.

${ }^{87}$ Kadıoğlu, 'Civil Society, Islam and Democracy in Turkey', p. 23

${ }^{88}$ M. Hakan Yavuz and Nihat Ali Özcan, 'Crisis in Turkey: The Conflict of Political Languages', Middle East Policy 14 (Fall 2007), pp. 118-135.

${ }^{89}$ Diane Singerman, 'Restoring the Family to Civil Society: Lessons from Egypt', Journal of Middle East Women's Studies 2(1) (2006), pp. 1-32.

${ }^{90}$ Bayat, 'Activism and Social Development in the Middle East'

${ }^{91}$ ibid, p. 12

92 Mona El-Ghobashy, 'The Metamorphosis of the Egyptian Muslim Brothers', International Journal of Middle East Studies 37(3) (2005), pp. 373-395. 
rights. These protests have permeated the country despite lack of central coordination among them and brutal state reaction. Fourth, another example of collaborative activism across the gamut of ideological spectrum can be found in the case of Kifaya. This was a coalition formed around common concerns regarding Egyptian foreign policy, Mubarak's election for a fourth term in 2005 , the emergency law, and the government intervention in the judiciary system ${ }^{93}$. The name chosen for the movement (enough) was reflective of the frustration of the participants in the face of more of the same in the political arena. Several analysts have seen in it the possibility for a new form of social and political activism ${ }^{94}$ because it cut across ideological divisions and participants seek to form broad alliances for successful political opposition. ${ }^{95}$ All of these activisms have culminated in the 2011 toppling of the Mubarak regime, fuelled also by numerous youth coalitions. Current reports on events in Egypt reveal the will to break free from the formalized rules of the game, exuberance, multifaceted nature, and messiness of revolutionary struggles.

In Lebanon, too, one is struck by the significance of community networks, particularly Islamist activism, as well as collaboration in moments of rupture. For instance, familial roles and metaphors have been instrumental in creating public spaces for women's work in Southern Lebanon. ${ }^{96}$ Today, especially in the southern suburbs of Beirut, Hizballah plays a significant role for the poverty-stricken population, most of whom are Shiite migrants from Southern Lebanon. These are effective networks, which rely on their proximity to the

\footnotetext{
${ }^{93}$ Mona El-Ghobashy, 'Egypt Looks Ahead to Portentous Year', Middle East Report Online, Feb 2, 2005, http://www.merip.org/mero/mero020205.html.

${ }^{94}$ Michaelle Browers, 'The Egyptian Movement for Change: Intellectual Antecedents and Generational Conflicts', Contemporary Islam 1(1) (2007), pp. 69-88; Manar Shorbagy, 'The Egyptian Movement for Change-Kefaya: Redefining Politics in Egypt', Public Culture 19(1) (2007), pp. 175-196.

95 Maha Abdelrahman, "With the Islamists? - Sometimes. With the State - Never!' Cooperation between the Left and Islamists in Egypt' British Journal of Middle Eastern Studies 36(1) (2006), pp. 37-54.

${ }^{96}$ Zeina Zaatari, 'The Culture of Motherhood: An Avenue for Women's Civil Participation in Southern Lebanon', Journal of Middle East Women's Studies 2(1) (2006), pp. 33-64.
} 
population, neighbourhood, provincial and kinship ties for both attracting participants and devising programs. ${ }^{97}$ While trust in political networks may have eroded significantly during and after the civil war, ${ }^{98}$ such ties continue to be significant for people. Furthermore, this is work made all the more powerful because it is recognized as part of the resistance against Israel in the border region of Lebanon. ${ }^{99}$ These organizations can become politically powerful because they speak to the constituents' everyday needs. ${ }^{100}$ Because activists adhere to Hizballah's interpretation of Islam and expect the same from participants and beneficiaries, some see in them the repetition of divisive patterns ${ }^{101}$ and proliferation of uncivic norms. Yet, scholars also point to the ability of such activism for dismantling myths about civic values by making more visible the contradictory deployments of "good" versus "bad" violence in Western discourses. ${ }^{102}$

The now popularly named Cedar Revolution following the assassination of Prime Minister Hariri in 2005 has also drawn attention to Lebanon. The assassination triggered widespread demonstrations, demanding the withdrawal of Syrian troops and the organization of an international commission to investigate the murder. Syrian troops withdrew within a few months, and an international commission was set up. The international tendency was to see these events as part of "colour revolutions" of Central and East Europe and Central Asia. What these accounts failed to note was the acrimonious opposition between the different parties concerning the role of the Syrian government in Lebanese politics. The confessional

\footnotetext{
${ }^{97}$ Mona Fawaz, 'Agency and Ideology in Community Services: Islamic NGOs in a Southern Suburb of Beirut', in: S.B. Nefissa, N.A. al-Fattah, S. Hanafi, \& C. Milani (eds) NGOs and Governance in the Arab World, (Cairo \& New York: AUC, 2005), pp. 229-256.

${ }^{98}$ Simon Haddad, 'The Relevance of Political Trust in Postwar Lebanon', Citizenship Studies 6(2) (2002), pp. 201-228.

${ }^{99}$ Fawaz, 'Agency and Ideology in Community Services', p. 234

${ }^{100}$ Guilain Denoeux, 'Promoting Democracy and Governance in the Arab World: Strategic Choices for Donors', in: S.B. Nefissa, N.A. al-Fattah, S. Hanafi, C. Milani (eds) NGOs and Governance in the Arab World, (Cairo \& New York: AUC, 2005), pp. 69-98.

${ }^{101}$ Fawaz, 'Agency and Ideology in Community Services', p. 245.

${ }^{102}$ Sadiki, 'Reframing Resistance and Democracy.'
} 
political structure, confrontational rhetoric among the leaders, transnational alliances and foreign intervention are still constitutive of Lebanese politics ${ }^{103}$. These problems relate to the complexities of civil society activism - including sectarian divisions, insufficient influence on political elite and the ambivalent practice of civic values.

These examples show that instead of formally organized and recognized CSO work, sometimes it is activisms that the political elite considers illegal or, at the very least, "undesirable" or "traditional," that have potential for political impact. The realities of everyday politics in the three cases reveal multiple forms of associational activity under persistent constraints. Owning up to the restrictions of CSOs has two interrelated effects. First, such a move captures both potential for and restrictions on political change through these networks. When civil society became a buzzword, it had its origins in the recent history of East Europe, where people successfully challenged authoritarian states through non-violent protests, made possible by widespread community mobilizations. They relentlessly demanded political and civil rights, thus transforming their associational networks into powerful political movements. ${ }^{104}$ CSOs endorsed by local and international governments and donors can fall short of capturing this intensity and grassroots activism. The net, therefore, needs to be cast wider. Yet, troubling hierarchies and the entrenchment of particular norms at the expense of others are likely to exist, limiting certain segments of society in many forms of associational life. Thus, we argue that the narrower approach to civil society (confined to studying CSOs and their impact on the democratization front) doesn't capture the complex reality on ground. Even though this may appear to signal a need to return to the broader definition, this too has to be qualified. CSOs emerge as the effect of overlapping state structures and policies, making a neat distinction between them analytically less plausible.

${ }^{103}$ Ersun Kurtuluş, “The Cedar Revolution': Lebanese Independence and the Question of Collective Self Determination', British Journal of Middle Eastern Studies 36(2) (2009), pp. 195-214.

${ }^{104}$ NeeraChandhoke, 'Civil Society', Development in Practice 17(August 2007), pp. 607-614. 


\section{Concluding Remarks: Is There an Alternative Perspective?}

Utilizing the self-evaluation of CSO actors in Egypt, Lebanon, and Turkey, the goal of this paper has been to contribute to debates about civil society activism and to reframe expectations concerning the link between robust CSOs and political liberalization. The value of the research on which this study is based stems from its participatory nature; focus on the actual experiences of people in civil society; and their willingness to reflect on the messiness of realities on the ground.

The results evidence the ways in which domestic governments and external donor states are present in overlapping networks, shaping the form and function of the CSO field. These overlapping networks raise questions about the indeterminate boundaries and organic connections between state and civil society actors. There are multiple ways to look into the indeterminacy of boundaries: domestic states enact and implement various laws that define who can safely become part of civil society. Many CSOs receive funding from their governments. The competition for this funding creates pressures to conform to what is considered "acceptable" activism. When the state is strong and repressive, CSO field is shaped as a result of restrictive legal requirements and pressure from state agencies toward conformity. These factors pose persistent obstacles and threats for those who aim to organize against the existing political situation in the countries. When the state is weak, it continues to shape the CSO field through its absence from welfare provisioning as well as piecemeal and ambiguous legislation, which leaves too much to the whims of bureaucrats in the everyday. Thus no matter what variations there may be in terms of regime types and state strengths, the boundary remains indeterminate, albeit in different ways.

In the case of international donors, the survey revealed the significance of this support for CSO survival. At the same time, however, there are three important qualifiers. First, donor 
prioritization of particular issues over others shapes the structure of CSO activism. Second, competition requirements impact who can receive funding and who cannot, determining and perpetuating comparative strength of organizations. Third, the tendency on the part of donor agencies and governments to conceptualize civil society in terms of those, which resemble their Western counterparts, can end up exaggerating the role of a limited number of CSOs. These myriad ways in which political power is exercised impact the shape of the CSO field.

These experiences reveal a distance between the definitions of civil society accepted by international donors and the nature of actual associational activity. CSOs are expected to occupy a space outside the state. However, they are integral to domestic and international states, in the nature of their formation and activities. While supporting the work done by these organizations, such an approach makes a case for reframing expectations. Because CSOs are never established on a blank slate and always embedded within existing power inequalities, their structures and activities can have limitations in initiating gradual political liberalization.

The survey and focus groups revealed multifarious results in terms of the practice and promotion of civic values and their impact. In all three cases, stakeholders emphasized that they upheld civic values, while, at the same time, acknowledging problems in internal practice. These problems attest to real possibilities for CSO field to repeat existing power inequalities. Rather than the absence of a realm autonomous from the state, more attention needs to be paid to nodes where power is concentrated in the hands of a minority of overlapping networks. ${ }^{105}$ As for impact, there is variation: while in Turkey, stakeholders saw real input in terms of human rights activism; in Lebanon and Egypt, they located their significance more in the field of development activism. This diversity connects with our previous discussion of donor prioritization.

\footnotetext{
${ }^{105}$ Timothy Mitchell, 'Dreamland: The Neoliberalism of Your Desires', Middle East Report 210 (Spring 1999), pp. 28-33.
} 
The general acknowledgement of lack of broad based participation takes us to our final point. In all three cases, there is more depth and breadth to associational activity than that of CSOs. A more rigorous analysis of civil society should canvass these diverse mobilization efforts and rethink international policy biases from this perspective. There are numerous ways in which ordinary people participate in channels of social change as well as reproduction of the status quo. Indeed, the experiences of the last two decades in Egypt, Lebanon, and Turkey, in general, and developments in Egypt since January 2011, in particular, exemplify the wider content of the civil activism. To challenge the conceptualization of civil society as a formally organized network that undercuts all sorts of divisions within society means we need to take into account all types of mobilization efforts. These may do more than induce gradual change: they can create conditions necessary for revolutionary regime transformation, as we are witnessing in events unfolding today.

Experiences and voices of CSO actors foreshadow these complexities. Comparing their own self-evaluations reveals that the distance between scholarly discussions of civil society and civil society practice is not as great as policy expectations make it sound. In fact, such a comparison across three countries of the region makes it possible to pay attention to nuances and specificities of context, while, at the same time, drawing out the more global predicaments of the relationship between civil society and political change. 